\title{
O tratamento dos conhecimentos linguísticos em aulas publicadas no Portal do Professor*
}

\author{
The approach of linguistic knowledge in classes published in the Teacher's Portal
}

\author{
Cássia Fernanda de Oliveira Costa** \\ Suzana Leite Cortez ${ }^{* * *}$
}

\begin{abstract}
RESUMO: A necessidade de uma abordagem da gramática a favor da reflexão e dos usos linguísticos é amplamente discutida entre linguistas e educadores desde a década de 80 . Nesse âmbito, surge a proposta teórico-metodológica da Análise Linguística (AL), que visa vincular o tratamento dos Conhecimentos Linguísticos (CL) ao trabalho com o texto. Apesar de defendidas por estu-diosos da língua e da educação - como Geraldi ([1984] 2006), Mendonça (2007), Ilari e Basso (2011), Bezerra e Reinaldo (2013) e Antunes (2014), que fundamen-tam teoricamente este trabalho - as mudanças em relação à abordagem dos CL ainda geram inquietações nos pro-fessores. Diante disso, propomo-nos a analisar aulas publicadas no Portal do Professor (plataforma on-line do Minis-tério da Educação voltada para docen-tes), no período de 2008 a 2016, para observar em que medida a proposta de trabalho com

ABSTRACT: The need for an approach to grammar in favor of reflection and the development of linguistic usage skills has been widely discussed among lin-guists and educators, especially since the 1980s. Within this approach, a theoreticalmethodological proposal that aims to link the treatment of Linguistic Know-ledge (LK) to work with the text emerges: Linguistic Analysis (LA). Despite being defended by scholars of language and education - such as Geraldi ([1984] 2006), Mendonça (2007), Ilari and Basso (2011), Bezerra and Reinaldo (2013) and Antunes (2014), which theoretically base this work - the proposals for change in relation to the LK approach still cause concern among Portuguese teachers. Therefore, we propose to analyze classes published by teachers in the Portal do Professor (online platform of the Mi-nistry of Education dedicated to the teaching public), in the period from 2008 to 2016, in
\end{abstract}

\footnotetext{
* Este trabalho é proveniente da dissertação de mestrado de Cássia Fernanda de Oliveira Costa, defendida em março de 2018, no Programa de Pós-Graduação em Letras da UFPE, área de Linguística, linha de pesquisa: Análise de práticas de linguagem no campo do ensino. A dissertação "A abordagem dos conhecimentos linguísticos no ensino de língua portuguesa: uma análise de aulas publicadas no Portal do Professor" foi orientada pela professora Suzana Leite Cortez.

** Mestre em Linguística pelo Programa de Pós-Graduação em Letras da Universidade Federal de Pernambuco. cassiacosta 93@hotmail.com

*** Doutora em Linguística pela Unicamp, e professora do Departamento de Letras e do Programa de Pós-Graduação em Letras da UFPE. sucortez@gmail.com
} 
os CL por meio da AL tem influenciado as projeções dos docentes para suas aulas, bem como compreender o que eles entendem por "AL". As análises evidenciaram que, mesmo categorizadas pelos professores-autores como de $\mathrm{AL}$, as aulas apresentam diferentes abor-dagens dos CL, que vão da inclinação à normatividade gramatical à abordagem textual-discursiva, em que se destaca o trabalho com o texto a favor da reflexão e dos usos linguísticos.

PALAVRAS-CHAVE: Conhecimentos Linguísticos. Análise Linguística. Abordagem textual-discursiva. Portal do Professor. Ensino de português. order to observe the extent to which the proposal of work with LK through linguistic analysis has influen-ced what teachers design for their classes, as well as to understand what the users of the Portal mean by "Linguistic Analysis". The analyzes led us to the understanding that, even if categorized as LA, the classes present different approaches to LK, ranging from inclina-tion to grammatical normativity to the work with the text in favor of reflection and linguistic uses.

KEYWORDS: Linguistic Knowledge. Linguistic Analysis. Portal do Professor. Portuguese Teaching.

\section{Introdução}

Dentre as lentas e importantes modificações pelas quais vem passando o ensino de língua portuguesa, as mudanças na abordagem dos conhecimentos linguísticos (CL) destacam-se como um dos aspectos que mais tem gerado debates no âmbito da linguística e da educação nas últimas quatro décadas. A extensa duração dos debates acerca desse aspecto do ensino de português provém do choque entre o enraizamento da gramática normativa nas práticas docentes e a natureza das mudanças propostas, que têm como ponto fulcral o deslocamento do "foco" das aulas de português da normatividade para a reflexão e os usos linguísticos.

Surge, nessa conjuntura, uma proposta teórico-metodológica para a abordagem dos conhecimentos linguísticos a favor do desenvolvimento das habilidades linguísticas de uso e reflexão: a Análise Linguística (AL). Elaborada inicialmente por Geraldi (2006) e difundida nos estudos sobre a abordagem dos CL na escola, essa proposta alcançou as instâncias de formação docente e documentos importantes para

a definição dos rumos da educação no país, como os Parâmetros Curriculares Nacionais (1997). 
Apesar disso, as propostas de mudança em relação à abordagem dos CL continuam levantando questionamentos e enfrentando certa resistência por parte das comunidades escolares. Conforme Bezerra e Reinaldo (2013), as inquietações e as resistências apresentadas por muitos professores em relação à abordagem dos CL voltada para os usos e para a reflexão - a que chamaremos abordagem textualdiscursiva dos CL - estão ligadas à própria formação do professor e à sua identidade docente (ainda marcada pela gramática normativa).

A fim de contribuir para o prosseguimento das discussões sobre esse tema, propomo-nos a analisar a abordagem dos CL em aulas publicadas no Portal do Professor (plataforma on-line do Ministério da Educação voltada para o público docente). Nesta análise, detemo-nos nas aulas publicadas sob a classificação de "aulas de AL" (classificação dada pelos professores-autores de acordo com temas definidos pela própria plataforma). Pretendemos, assim, analisar como as propostas de prática de AL e a abordagem textual-discursiva dos CL têm influenciado o que os docentes projetam para suas práticas, o que nos levará a compreender o que tais aulas demonstram do entendimento dos professores sobre a AL.

Nosso interesse em empreender esta pesquisa foi fortalecido pela constatação, através de um levantamento realizado em 2017 no Banco de Teses e Dissertações da Capes $^{1}$, da escassez de trabalhos relacionados ao Portal do Professor e da inexistência de pesquisas que contemplassem a abordagem dos CL nas aulas publicadas na plataforma.

Para fundamentar teoricamente este trabalho, utilizamo-nos das contribuições acerca da história da gramática e da disciplina de Língua Portuguesa no Brasil, provenientes de autores como Neves (2015) e Soares (1998, 2001); e dos estudos sobre a AL e a abordagem textual-discursiva dos CL, de autores como Geraldi $(1997,2006)$, 
Franchi (1977, 2006), Mendonça (2006, 2007), Possenti (1984, 1996), Antunes (2003; 2014), Bezerra e Reinaldo (2013) e Perini (2014).

\section{Língua, ensino e conhecimentos linguísticos}

A partir da década de 80, eclodiram com maior veemência, por parte de estudiosos da linguagem e da educação, muitas críticas em relação ao ensino de língua portuguesa então realizado na escola. Percebeu-se que o enfoque metalinguístico dos incontáveis exercícios de repetição estrutural e de preenchimento de lacunas não contribuía, de fato, para o desenvolvimento das habilidades de uso linguístico e reflexão sobre a linguagem, nem mesmo se mostrava eficaz na apreensão da norma culta $^{2}$.

Como considera Rangel (2001), essa grande mudança na concepção de ensino de língua materna constituiu-se como um fruto tardio da virada pragmática, advinda tanto das ciências da aprendizagem quanto das ciências da linguagem. Esse novo olhar sobre o ensino de língua materna fundamentou-se no surgimento da concepção de língua que a considera como processo de interação. Nessa concepção, à qual nos filiamos teoricamente, mais do que possibilitar a transmissão de informações de um emissor a um receptor, a linguagem é vista como um lugar de interação humana. Por meio dela, o sujeito que fala pratica ações que não conseguiria levar a cabo, a não ser falando; com ela o falante age sobre o ouvinte, constituindo compromissos e vínculos que não preexistiam à fala (GERALDI, 2006, p. 41).

Leva-se em consideração, dessa maneira, o contexto em que a língua é utilizada, tanto na modalidade oral quanto na escrita, pois essa visão de língua concebe todo e qualquer uso linguístico como situado sócio-historicamente. Outra consequência da adoção dessa forma de compreensão da língua é o entendimento de que não há entre

\footnotetext{
${ }^{2}$ Cf. Antunes (2014).
} 
as variantes linguísticas nenhuma diferença de "qualidade", o que existem são diferentes valorações sociais atribuídas a tais variantes ${ }^{3}$.

Essas valorações, tal como aponta Marcuschi (2008), são entendidas como uma consequência do caráter social, histórico, político e ideológico que é constitutivo do fenômeno linguístico. Destarte, conforme argumenta Geraldi (2006), é no próprio funcionamento da língua - isto é, nos contextos reais de uso - que se estabelecem as "regras" que o determinam. Assumir tais pressupostos, todavia, não implica a negação do caráter sistemático que também faz parte da constituição da língua, como explicita Marcuschi (2008, p. 62): “quando se fala em uso e função, não se ignora a existência de formas. Apenas frisa-se que as formas não são tudo no estudo da língua e que as formas só fazem sentido quando situadas em contextos sociointerativamente relevantes".

Quando relacionados ao ensino, os pressupostos da noção de língua como processo de interação têm por objetivo aprimorar as habilidades dos estudantes em relação ao uso e à reflexão sobre a língua, por meio da priorização do texto, oral ou escrito, em diferentes gêneros. O texto passa a ser, então, o foco das aulas de português, pois é através de sua manifestação em gêneros que são constituídas as práticas sociais. Portanto, o trabalho com a língua portuguesa "[...] teria de se ocupar com algo mais do que o ensino e aprendizagem de regras ou normas de boa formação de sequências linguísticas. Trata-se de um estudo em que se privilegia a variada produção e suas contextualizações na vida diária" (MARCUSCHI, 2008, p. 76).

Ao tomarmos a língua como processo de interação, o conceito de gramática, consoante Soares (1998, p. 59), "ultrapassa o nível da palavra e da frase e traz nova orientação para o ensino da leitura e da produção de textos". Assim, no ensino de língua portuguesa que se baseia nessa concepção, a leitura, a produção (oral e escrita) e os conhecimentos linguísticos (CL) - ou seja, as reflexões sobre a língua e sua

\footnotetext{
${ }^{3}$ Cf. Antunes (2014).
} 
sistematização - constituem os três sustentáculos, chamados de "eixos", em torno dos quais se organiza a prática pedagógica. Como elucida Bunzen (2014), a inter-relação desses eixos na sala de aula objetiva a formação de leitores e produtores de textos competentes.

A relação apontada por Soares (1998) e Bunzen (2014) entre a gramática e os eixos da leitura e da produção evidencia que, nessa concepção, os CL são sempre mobilizados a favor dos usos reais da língua, de forma situada histórica, social e ideologicamente. Tais princípios não devem ser confundidos com um descaso pelo trabalho com os CL na aula de língua portuguesa. A reflexão sobre os elementos intralinguísticos não deve ser abandonada ou relegada a segundo plano, pois, como expõe Antunes (2014), não existe língua sem a organização intralinguística que representa a gramática. Essa organização, porém, nunca se desvincula da conjuntura sócio-histórica que a determina, pois “[...] a gramática, enquanto elemento constitutivo das línguas, é sempre contextualizada, uma vez que nada do que dizemos - oralmente ou por escrito - acontece em abstrato, fora de uma situação concreta de interação" (ANTUNES, 2014, p. 39).

\section{Abordagem textual-discursiva dos conhecimentos linguísticos}

Denominamos como textual-discursiva a abordagem dos CL pautada na concepção de língua como forma de interação. Essa abordagem caracteriza-se por priorizar a produção de sentidos no trabalho com os diferentes níveis de análise da língua (sintático, morfológico, semântico). Nela, o exame de formas linguísticas e de normas de funcionamento das diferentes variantes da língua está sempre vinculado à análise dos sentidos do texto e das circunstâncias nas quais se situa o discurso. ${ }^{4}$

\footnotetext{
${ }^{4}$ Conforme indica Marcuschi (2008), a distinção entre texto e discurso não é rígida. Mas, de maneira geral, o discurso constitui o objeto do dizer, enquanto o texto corresponde ao objeto de figura. Isto é: “o discurso dar-se-ia no plano do dizer (a enunciação) e o texto no plano da esquematização (a
} 
O emprego da denominação textual-discursiva para fazer referência a esse tipo de abordagem dos CL é proveniente das resenhas de avaliação de livros didáticos publicadas nos Guias do Programa Nacional do Livro Didático (PNLD) em 2014 e em 2017. Essa abordagem reflexiva dos CL opõe-se à abordagem designada nas resenhas como "morfossintática" - denominação que também utilizaremos neste trabalho. De maneira contrastante ao que ocorre no tratamento textual-discursivo, na abordagem morfossintática os CL são tomados de forma desvinculada dos usos, assim os aspectos morfológicos e sintáticos são analisados sem que sejam consideradas suas relações com o sentido (o que corresponde ao chamado "ensino tradicional de gramática").

Em consonância com o que esclarecem autores como Antunes (2014), Soares (1996) e Possenti (1984), entendemos que a opção por uma abordagem textualdiscursiva dos CL é, também, uma opção política. Por favorecer o desenvolvimento das habilidades de uso, bem como as de reflexão sobre o funcionamento da língua, o tratamento textual-discursivo dos CL proporciona aos estudantes a perspicácia linguística necessária para desvelar sentidos e posicionar-se dignamente em prol de seus direitos, o que consiste em uma parte essencial de sua formação como cidadão crítico, pela qual a escola é responsável ${ }^{5}$.

É também por razões políticas que o ensino da norma culta, ou a criação de condições para que ela seja aprendida ${ }^{6}$, é considerado um dos objetivos da aula de língua portuguesa em uma abordagem textual-discursiva. Isto não se dá por uma questão de superioridade dessa variedade em relação às outras, mas pela necessidade de possibilitar o acesso do alunado aos contextos em que circula a variedade culta. Destarte, o trato textual-discursivo da gramática - aqui entendida como conjunto de leis discursivamente determinadas que regem a estruturação da língua em seus usos

configuração). Entre ambos, o gênero é aquele que condiciona a atividade enunciativa" (MARCUSCHI, 2008, p. 82).

${ }^{5}$ Cf. Antunes (2014).

${ }^{6}$ Cf. Possenti (1984). 
reais, tal como elucida Neves (2015) - não exclui o desenvolvimento das habilidades de uso da norma culta e as reflexões sobre essa variedade, mas implica a não exclusão das demais variedades nesses mesmos processos.

Além da face política, o empreendimento de um estudo de base textualdiscursiva dos CL pode contribuir também para a formação científica dos estudantes. Ao defender tal posicionamento, Perini (2014) argumenta que o estudo escolar da gramática deve ser empreendido como os das demais disciplinas científicas, ou seja, com base na observação dos fatos - o que faz emergir a necessidade de considerar-se o contexto de uso, bem como as práticas sociais que através da língua são empreendidas -, no levantamento de hipóteses e na sistematização.

Em conformidade com o que argumenta o autor, tais características são incompatíveis com o ensino tradicional de português, porque, para que os estudantes fomentem um pensamento analítico sobre a linguagem, a gramática não pode ser tomada como uma listagem prescritiva, nem como um sistema alheio aos falantes, sobre o qual estes não têm influência significativa. Como alerta Perini (2014, p. 55), “a ciência é o caminho, não o ponto de chegada". Assim, o objetivo de uma abordagem textual-discursiva dos CL não é o de que sejam memorizadas proibições ou classificações morfossintáticas, mas o de que o estudante analise e compreenda o funcionamento da língua.

De tal forma, a aula em que os CL são abordados pela análise do texto e do discurso é um espaço aberto para os questionamentos e para as especulações, sem brechas para as crenças valorativas e os dogmas linguísticos ${ }^{7}$. A proposta de Mário Perini está em consonância com o que apresenta Carlos Franchi em relação à gramática e ao seu vínculo com a criatividade. Tal como Perini (2014), Franchi (2006) considera que os CL devem ser abordados na escola de maneira que os alunos tenham a oportunidade de "manejar" a língua, experimentando suas possibilidades e

\footnotetext{
${ }^{7}$ Cf. Perini (2014).
} 
explorando as relações entre formas e sentidos. $\mathrm{O}$ autor esclarece que proceder dessa maneira representa um exercício de criatividade linguística e possibilita que os estudantes desenvolvam suas habilidades de analisar e refletir sobre a própria língua, além de prover o aumento do repertório linguístico dos alunos.

Incorporar a criatividade, elemento constituinte da língua, ao trabalho com os CL nas aulas de português equivale, portanto, a tratar cientificamente o estudo da gramática, pois tal incorporação exige o "manuseio" da língua como em um "laboratório". Desassociar a gramática do texto e do discurso inviabiliza esse processo, pois através dessa desvinculação, tão comum no ensino tradicional, "faz-se da linguagem um objeto morto para biópsias e autópsias da segmentação, da análise, da classificação" (FRANCHI, 2006, p. 76).

\subsection{Níveis de atividade e prática de Análise Linguística}

As propostas de Franchi (2006) e de Perini (2014) em relação às práticas que conduzam os estudantes a "manipular" a língua, criando hipóteses e, posteriormente, sistematizando seus conhecimentos sobre ela, são orientadas pela distinção de três níveis de atividades: linguísticas, epilinguísticas e metalinguísticas. Realizada por Franchi no final da década de 80 e corroborada por Geraldi (1997), essa distinção não diz respeito a atividades no sentido de "tarefas" ou "exercícios", mas refere-se às ações linguísticas empreendidas no jogo da interação para que os sentidos sejam construídos. Assim, “dependendo da intencionalidade do professor, o processo de ensino e aprendizado pode enfatizar alguma atividade específica. Para a realização destas, deve-se sempre partir da noção de que a linguagem é um fenômeno social e que se concretiza em textos" (SANTOS, 2017, p. 138).

As atividades linguísticas representam o próprio uso da linguagem, em sua modalidade oral ou escrita. Esse nível de atividade constitui, então, "nada mais que o exercício pleno, circunstanciado, intencionado e com intenções significativas da 
própria linguagem" (FRANCHI, 2006, p. 95). Já as atividades epilinguísticas são aquelas que "resultam de uma reflexão que toma os próprios recursos expressivos como seu objeto" (GERALDI, 1997, p. 23). Como esclarecem Franchi e Geraldi, os três níveis de atividades não ocorrem de maneira isolada. Dessa forma, as atividades epilinguísticas podem ocorrer no interior de uma atividade linguística: "nas negociações de sentido, em hesitações, em autocorreções, reelaborações, rasuras, pausas longas, repetições, antecipações, lapsos etc." (GERALDI, 1997, p. 24).

Em suma, denomina-se epilinguística toda atividade de reflexão sobre o fenômeno linguístico, tanto em relação ao âmbito estrutural quanto ao discursivo. Esse nível de atividade é desempenhado pelos falantes de uma língua desde o processo de aquisição, por isso é promovido pelas pessoas muitas vezes de maneira desapercebida. $\mathrm{Na}$ escola, explorar a atividade epilinguística constitui uma maneira eficaz de trabalhar os CL sob o prisma da abordagem textual-discursiva. É precisamente nesse nível de atividade que se pode estimular os estudantes a observarem o funcionamento da língua e a levantarem hipóteses sobre ele, para então reformular maneiras de dizer, de atenuar ou de reforçar sentidos, operando sobre a própria linguagem ${ }^{8}$.

O terceiro e último nível é o da atividade metalinguística. Nesse nível de atividade, a vivência da língua e as reflexões promovidas sobre ela, propiciadas pelos níveis linguístico e epiliguístico, são sistematizadas. São atividades em que os sujeitos "conscientemente constroem uma metalinguagem sistemática com a qual falam sobre a língua" (GERALDI, 1997, p.25). É nesse nível de atividade que os fenômenos linguísticos são agrupados em classificações e recebem denominações específicas. Ao contrário dos níveis anteriores, esse tipo de atividade não é comum fora dos espaços escolares, por isso seu desenvolvimento tem ligação com o nível de escolaridade dos falantes.

\footnotetext{
${ }^{8}$ Cf. Franchi (2006).
} 
Ao distinguir tais níveis de atividade, Franchi (2006) destaca que a predominância das atividades linguísticas e epilinguísticas nas aulas de língua portuguesa de todos os níveis da vida escolar é essencial, sobretudo nas primeiras séries. A atividade metalinguística, porém, não está excluída do trabalho com os CL em um viés textual-discursivo, ela é fundamental no processo de sistematização do conhecimento, mas precisa resultar "de uma larga familiaridade com os fatos da língua, como decorrente de uma necessidade de sistematizar um 'saber' linguístico que se aprimorou e que se tornou consciente" (FRANCHI, 2006, p. 98-99).

Esse posicionamento em relação à metalinguagem é asseverado por Antunes (2003), que ressalta o fato de que o conhecimento explícito das regras de funcionamento da língua proporcionado pela metalinguagem está, na abordagem textual-discursiva, a favor do enriquecimento e da ampliação das reflexões sobre o fenômeno linguístico. Portanto, a atividade metalinguística não está voltada a si mesma como ocorre no ensino tradicional de português.

No âmbito da abordagem textual-discursiva dos CL, uma proposta teóricometodológica de articulação entre os eixos deste, da leitura e da produção textual ganhou destaque no cenário nacional graças à sua influência em documentos como os Parâmetros Curriculares Nacionais (1997). Essa proposta de articulação, ou simplesmente a Análise Linguística (AL), até os dias atuais tem pautado o trabalho com os CL a favor da produção e da compreensão de sentidos, sendo também sustentada pela avaliação de livros didáticos promovida, até então, pelo Programa Nacional do Livro Didático (PNLD) e pelas instâncias de formação inicial e continuada de professores.

A expressão Análise Linguística, tal como esclarece Bezerra e Reinaldo (2013), é bastante abrangente por ser utilizada nos estudos da língua para designar questões muito distintas. A acepção pedagógica dessa expressão, para a qual está voltado nosso interesse neste trabalho, foi cunhada por Geraldi [1984]. Assim, a AL consiste em uma 
proposta metodológica alicerçada na abordagem textual-discursiva dos CL. Como já pontuamos, é em Geraldi (2006) que podemos encontrar a primeira proposta de prática de AL. Ele salienta que

O uso da expressão "prática de análise linguística" não se deve ao mero gosto por novas terminologias. A análise linguística inclui tanto o trabalho sobre as questões tradicionais da gramática quanto questões amplas a propósito do texto, entre as quais vale a pena citar: coesão e coerência internas do texto, adequação do texto aos objetivos pretendidos; análise dos recursos expressivos utilizados (...); organização e inclusão de informações etc (GERALDI, 2006, p. 74).

Para que esses objetivos sejam alcançados, o autor propõe que a prática de AL seja realizada com base em textos produzidos pelos próprios estudantes, o que oportuniza a autocorreção e a promoção de um ensino de língua que prioriza a produção de conhecimento em lugar do simples reconhecimento promovido pelo ensino que se funda em conceitos já acabados para exercícios de fixação. De tal forma, a prática de AL está centrada na reflexão sobre a língua em prol das habilidades de uso, portanto é desenvolvida no âmbito das atividades epilinguísticas e metalinguísticas, tal como explicita Geraldi (1997, p. 189):

Com a expressão "análise linguística" pretendo referir precisamente este conjunto de atividades que tomam uma das características da linguagem como seu objeto: o fato de ela poder remeter a si própria, ou seja, com a linguagem não só falamos sobre o mundo ou sobre nossa relação com as coisas, mas também falamos sobre como falamos. Como já vimos, a estas atividades têm sido reservadas as expressões "atividades epilinguísticas" ou "atividades metalin-guísticas".

A prática de $\mathrm{AL}$ dá maior relevância às atividades epilinguísticas, pois, ao considerar a natureza dessas atividades, tem-nas como "condição para a busca significativa de outras reflexões sobre a linguagem" e "ponte para a sistematização metalinguística" (GERALDI, 1997, p. 191-192). Sendo assim, consoante Bezerra e 
Reinaldo (2013), a AL elege o texto como unidade de ensino da disciplina de Português, pois só nele e através dele as atividades epilinguísticas encontram solo fértil para seu desenvolvimento. Consequentemente, podemos depreender que a prática de AL está vinculada ao trabalho com os gêneros textuais, pois “[...] o texto, tal como construído em cada situação de interação, remete às convenções de um ou mais gêneros cujos propósitos comunicativos predominam na situação específica" (BEZERRA, 2017, p. 37).

Acerca do papel do texto na prática de AL, Antunes (2014) traz importantes esclarecimentos. Segundo ela, muitas vezes práticas tradicionais de ensino de gramática, em que os conteúdos são abordados em uma perspectiva exclusivamente morfossintática, são "mascaradas" pela mera presença de textos, tomados como repositório de exemplos para os exercícios de classificação e identificação. A autora alerta-nos, assim, para o seguinte fato:

Mesmo quando se pretende focalizar questões de gramática, não se pode deixar de ver o texto como um todo, quer dizer: seu tema global, sua finalidade central, [...] o universo de referência em que se inclui, o gênero que atualiza, seus padrões de construção etc. Quer dizer, não se deve separar a dimensão gramatical das outras dimensões que fazem a significação do texto (ANTUNES, 2014, p. 115-116, grifos da autora).

Apesar de todas as orientações oficializadas por documentos como os PCN e do amplo debate realizado desde a década de 80 nas universidades e nas escolas, a abordagem textual-discursiva dos $\mathrm{CL}$, e consequentemente a prática de $\mathrm{AL}$, continua sendo um desafio para os professores e, também, para os cursos de Letras que formam esses profissionais. Esse cenário de resistência deve-se ao fato de que a mudança de perspectiva no ensino de língua portuguesa, sobretudo em relação à gramática, desencadeia um quadro de incertezas devido, de um lado, à confusão decorrente de críticas feitas à gramática tradicional pelo discurso da mudança, provocando dúvida sobre qual prática linguística desenvolver na sala de aula; e, de outro, devido à não 
compreensão por parte dos professores do que significa ensinar a língua com base no texto e/ou nos usos linguísticos (KHUN; FLORES, 2008 apud BEZERRA; REINALDO, 2013, p. 16).

Tendo em vista a complexidade de tal conjuntura e considerando o quanto os planos de aula elaborados pelos docentes podem revelar acerca das perspectivas teórico-metodológicas por eles adotadas, analisamos nesta pesquisa aulas publicadas em domínio público no Portal do Professor.

\section{O Portal do Professor}

No intuito de analisar o que as aulas propostas por professores de língua portuguesa demonstram de seu entendimento acerca da $A L$, bem como a maneira pela qual as propostas de prática de AL e a abordagem textual-discursiva dos CL têm influenciado no que esses docentes projetam para suas práticas, constituímos o corpus de nossa pesquisa por meio de aulas ${ }^{9}$ publicadas no Portal do Professor.

O Portal é organizado em seções, conforme os recursos disponibilizados em cada uma delas. Essa organização pode ser vista assim que o usuário acessa o site da plataforma, em sua página inicial, como mostra a Figura 1:

Figura 1 - Seções do Portal.

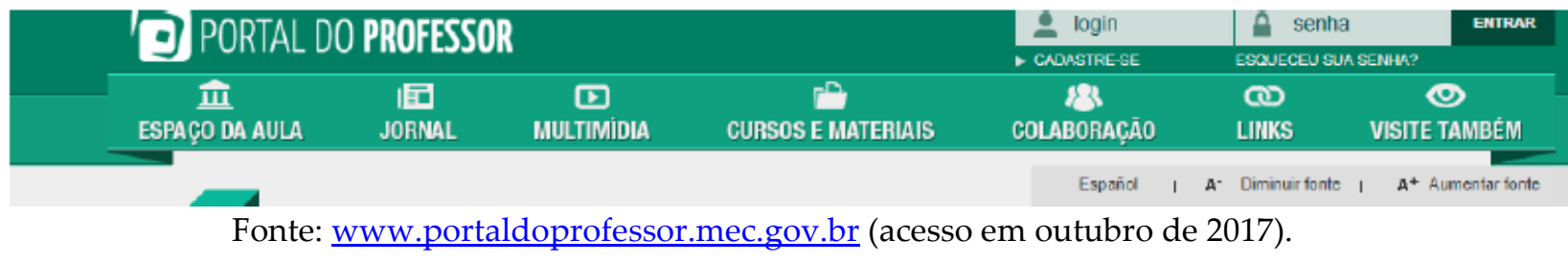

\footnotetext{
${ }^{9}$ A escolha do termo "aula" para designar as publicações do Portal do Professor deu-se graças ao uso desse termo no âmbito do próprio portal. Não ignoramos, no entanto, o fato de que a "aula" propriamente dita é um evento comunicativo muito mais complexo, que envolve não só as atividades desenvolvidas e os conteúdos trabalhados, mas também a interlocução entre professores e alunos, a conjuntura social em que está situada a escola etc.
} 
Nossa análise no portal se limita à seção Espaço da Aula. Ao clicar nessa seção, o usuário tem algumas opções. A primeira, "Sugestões de aula", direciona-o às aulas já publicadas e disponíveis para visualização e download. As aulas estão agrupadas no Portal de acordo com a modalidade de ensino, o nível e o componente curricular. Para cada componente curricular (Português, Matemática, História, Geografia etc.) há "temas" definidos pela própria plataforma, de acordo com os conteúdos amplos de cada um deles. Nesta pesquisa, detemo-nos nas aulas direcionadas ao trabalho com os CL, por isso estabelecemos como critério de seleção para nosso corpus que as aulas estivessem categorizadas em pelo menos um dos temas relativos a eles. Dessa maneira, nossa análise contempla apenas os temas determinados pelo Portal indicados no quadro abaixo:

Quadro 1 - Temas do Portal diretamente relacionados aos CL.

\begin{tabular}{|c|c|}
\hline Temas do Ensino Fundamental & Temas do Ensino Médio \\
\hline Análise Linguística: léxico e redes semânticas & $\begin{array}{c}\text { Produção, leitura, análise e reflexão sobre } \\
\text { linguagens }\end{array}$ \\
\hline $\begin{array}{l}\text { Análise Linguística: modos de organização dos } \\
\text { discursos }\end{array}$ & $\begin{array}{l}\text { Recursos linguísticos em uso: fonológicos, } \\
\text { morfológicos, sintáticos e lexicais }\end{array}$ \\
\hline $\begin{array}{l}\text { Análise Linguística: organização estrutural dos } \\
\text { enunciados }\end{array}$ & - \\
\hline $\begin{array}{l}\text { Análise Linguística: processos de construção } \\
\text { de significação }\end{array}$ & - \\
\hline $\begin{array}{c}\text { Análise Linguística: variação linguística - } \\
\text { modalidades, variedades, registros }\end{array}$ & - \\
\hline
\end{tabular}

Fonte: elaborado pelas autoras.

A seleção das aulas para a construção de nosso corpus deu-se de acordo com a ordem de relevância estabelecida pelo próprio Portal do Professor (baseada no número de acessos e de comentários recebidos por cada aula) e por uma análise em que levamos em consideração o eixo de ensino de português tomado como foco em cada aula. Essa análise mostrou-nos que, apesar de classificadas como de AL, algumas das aulas não tinham como foco os CL. Assim, tais aulas foram excluídas de nosso corpus, 
que foi delimitado a 33 aulas categorizadas no Portal nos temas voltados à AL e que apresentam os CL como conteúdo.

A análise de nosso corpus evidenciou que entre as aulas analisadas há graus diferentes de aproximação ou de distanciamento da prática de AL. Desse modo, a abordagem tradicional - predominantemente morfossintática - e a textual-discursiva nem sempre se apresentam "puras" ou de maneira estanque. Entre um tratamento textual-discursivo e um tratamento puramente morfossintático dos CL existem muitas nuances.

Dessa maneira, agrupamos as aulas de acordo com o tipo de abordagem dada aos CL. Para tanto, chegamos à construção de cinco categorias fundadas em traços que julgamos relevantes e recorrentes em nosso corpus. As cinco categorias estabelecidas são: 1. abordagem morfossintática tradicional; 2. abordagem sintático-semântica em consonância com nomenclaturas e conceitos da GT; 3. abordagem sintático-semântica a partir do texto; 4. abordagem textual-discursiva; e 5. abordagem teórica de conceitos da linguística. A caracterização de cada uma dessas categorias será detalhada na seção seguinte, em que realizaremos nossa análise.

\section{Análise das aulas publicadas no Portal}

Como indicamos na seção anterior, as aulas de nosso corpus foram classificadas em cinco categorias, de acordo com as características de cada uma delas em relação à abordagem dos CL. As categorias representam uma "escala" que abrange das aulas mais distantes às mais próximas da abordagem textual-discursiva, quer dizer, das aulas que mantêm os traços típicos do ensino prescritivo e puramente estrutural de gramática àquelas em que se identificam as contribuições de estudos do texto e do discurso. As 33 aulas estão distribuídas nessas categorias, conforme mostra o gráfico a seguir: 


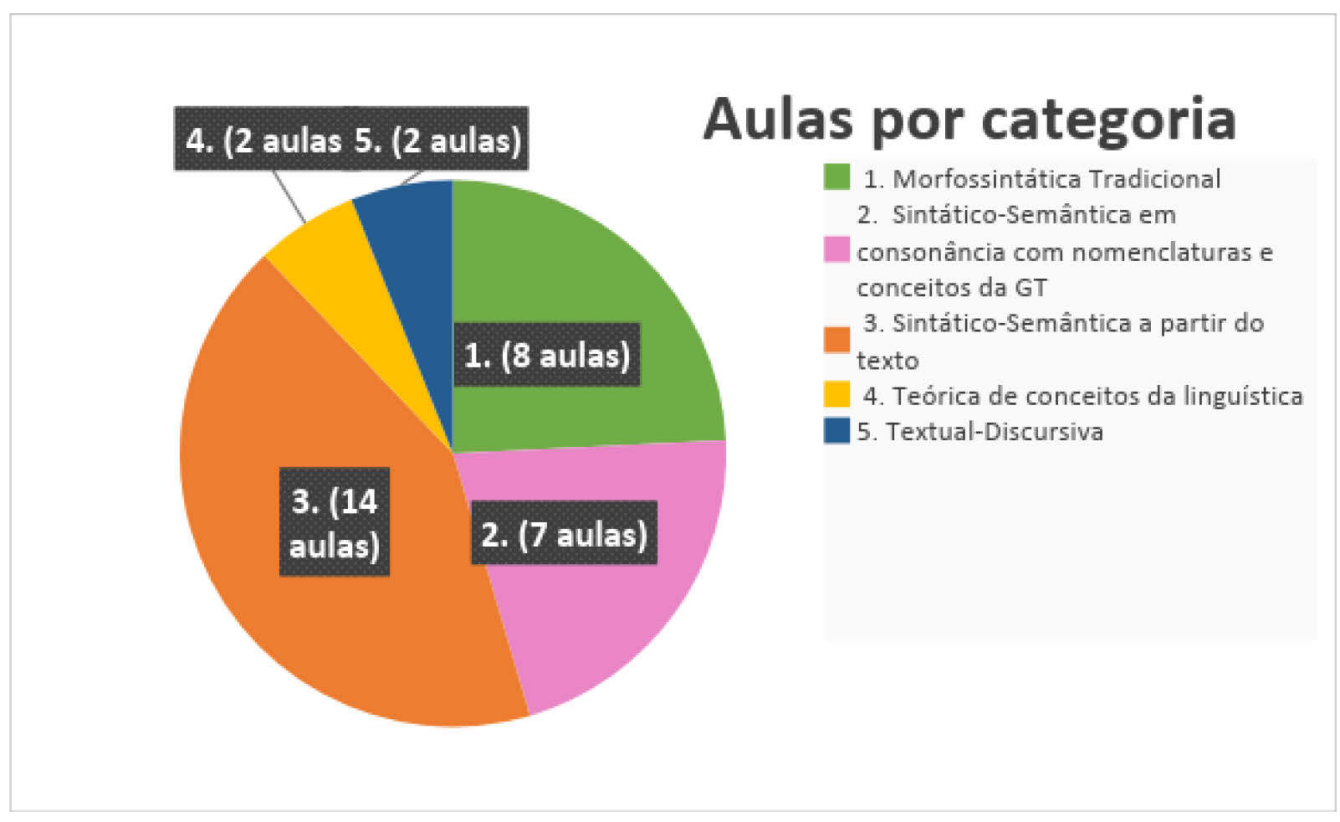

Fonte: elaborado pelas autoras.

Ao realizarmos a tipificação dessas categorias, pudemos elencar as principais características de cada uma delas, como mostra de maneira sintetizada o quadro a seguir:

Quadro 2 - Tipificação das aulas.

1. Abordagem morfossintática tradicional: primazia da metalinguagem; exercícios de identificação e de classificação; texto como pretexto e tomada da frase ou da palavra como unidade de análise.

2. Abordagem sintático-semântica em consonância com nomenclaturas e conceitos da gramática tradicional (GT): uso das categorias estabelecidas pela GT e valorização da metalinguagem; análise superficial dos efeitos de sentido, de maneira limitada às possibilidades oferecidas pela GT; mescla de exercícios de classificação/identificação e exercícios de reflexão sobre os usos da língua/efeitos de sentido; texto como pretexto e frase como unidade de análise.

3. Abordagem sintático-semântica a partir do texto: uso moderado ou pouco uso da metalinguagem gramatical; influência de teorias linguísticas (como as relacionadas aos gêneros textuais e à variação linguística); articulação superficial com os eixos da leitura e da produção oral ou escrita. 
4. Abordagem teórica de conceitos da linguística: influência de teorias linguísticas (como as relacionadas à linguística textual e à sociolinguística); tratamento teórico de conceitos da linguística (como os de gênero, variação, coesão e coerência), com pouca ou nenhuma exploração dos usos efetivos da língua.

5. Abordagem textual-discursiva: predominância de atividades epilinguísticas; atividades que promovem reflexões acerca dos usos da língua e da produção de sentidos; texto como unidade de análise; articulação com os eixos da leitura e da produção oral e escrita; uso da metalinguagem para a sistematização do conhecimento.

Para viabilizar a compreensão de como se materializam nas aulas as características dessas abordagens, analisaremos exemplos de atividades extraídos de aulas pertencentes a cada uma das cinco categorias tipificadas.

\subsection{Abordagem morfossintática tradicional}

Dentre as aulas da abordagem morfossintática tradicional, está a aula 5 do nosso corpus, intitulada "Aprendendo com os erros dos outros: uma análise de erros gramaticais em placas, anúncios e produtos". A filiação dessa aula à abordagem morfossintática tradicional é manifesta desde o seu título, em que se utiliza o conceito de "erro gramatical" para fazer referência a usos da língua distintos da norma culta.

Em uma das atividades, o professor-autor propõe que os alunos sejam divididos em grupos de quatro a cinco integrantes, para os quais devem ser distribuídas folhas de papel em branco. Após a divisão dos grupos, sugere-se que sejam apresentados aos alunos exemplos de "placas e anúncios com erros de português". Algumas sugestões de exemplos são trazidas pela atividade, como as que apresentamos a seguir: 
Exemplo 1 - 2a atividade da aula 5: "Placas e anúncios com erros de português".
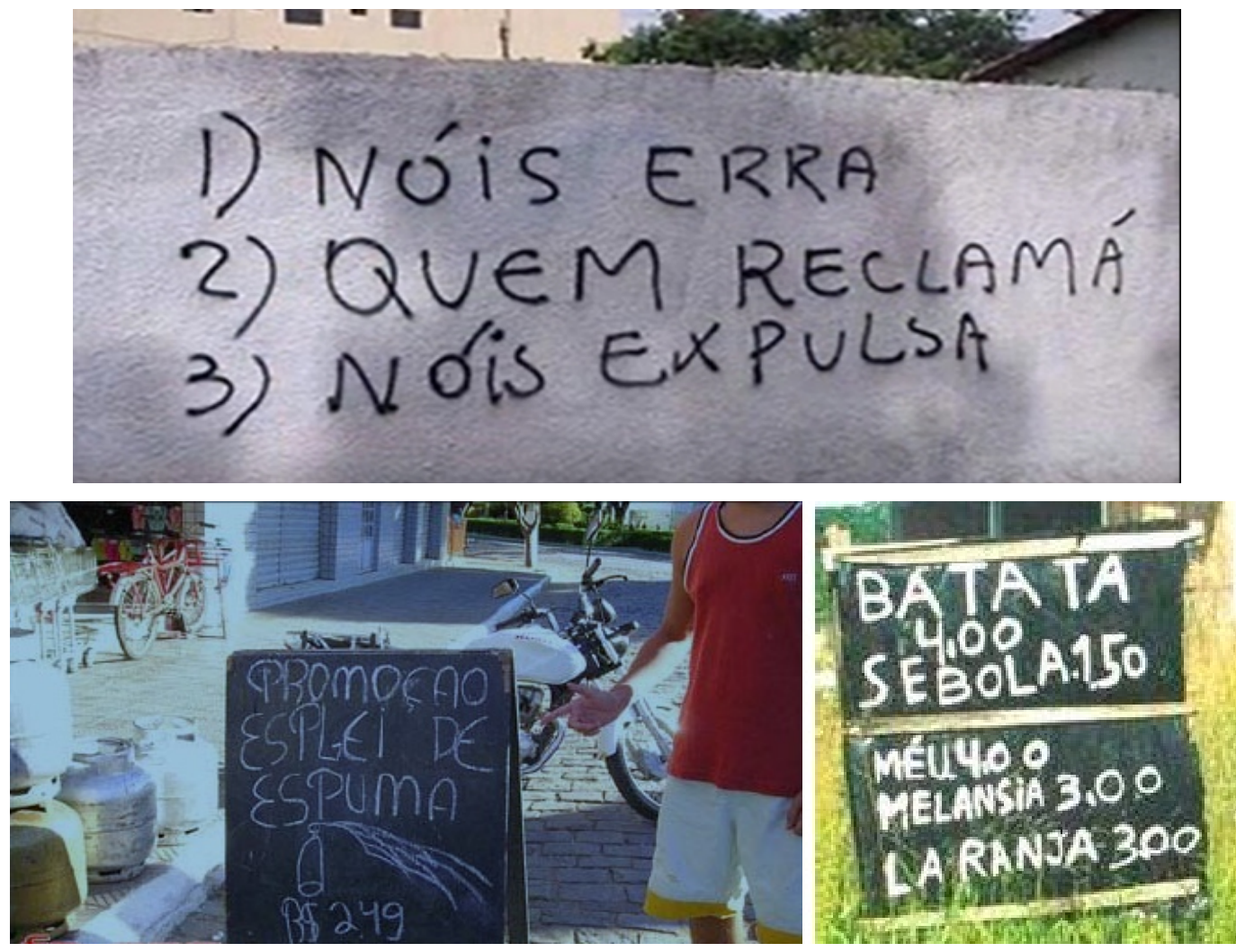

Fonte: $\mathrm{http}: / /$ portaldoprofessor.mec.gov.br/fichaTecnicaAula.html?aula=6471

Segundo a sugestão dessa proposta de aula, os grupos devem ser orientados a identificar os erros em cada exemplo apresentado e anotá-los na folha de papel. Em seguida, cada grupo deve corrigir os erros identificados com a ajuda de dicionários. Ao final da atividade, o professor confere as correções de cada grupo e verifica qual deles teve mais acertos.

Ao desconsiderar a produção de sentidos, essa atividade propõe um trabalho de "higienização" linguística que não contribui para o desenvolvimento das habilidades de análise dos alunos em relação à estrutura da língua e sua relação com os usos. A atividade não considera, por exemplo, que em alguns dos textos apresentados para correção não se trata de placas ou de anúncios, o que ocorre na primeira imagem do Exemplo 1 é uma pichação. Por pertencer a outro gênero, esse texto tem propósitos comunicativos distintos dos de um anúncio. Com base no conhecimento de que as pichações são utilizadas como forma de protesto, de crítica ou 
de afronta ao status quo, seria possível levantar a hipótese de que os desvios da norma culta presentes no exemplo analisado podem ser propositais, utilizados como recurso para a produção de sentidos.

Também são exemplos de propostas que partilham das características da abordagem morfossintática tradicional as atividades da aula 25, intitulada "Período composto por subordinação: orações subordinadas substantivas":

Exemplo $2-2^{-a}$ atividade da aula 25

\section{Exercício 2}

Acessem, em apenas um laptop por dupla, os links relacionados abaixo, em que visualizarão diferentes tiras humorísticas e respondam às questões propostas sobre cada uma delas:

1) Leiam a tira abaixo e respondam:

(Disponível em: http://www.propagar3.com.br/index.php/tag/hagar/)

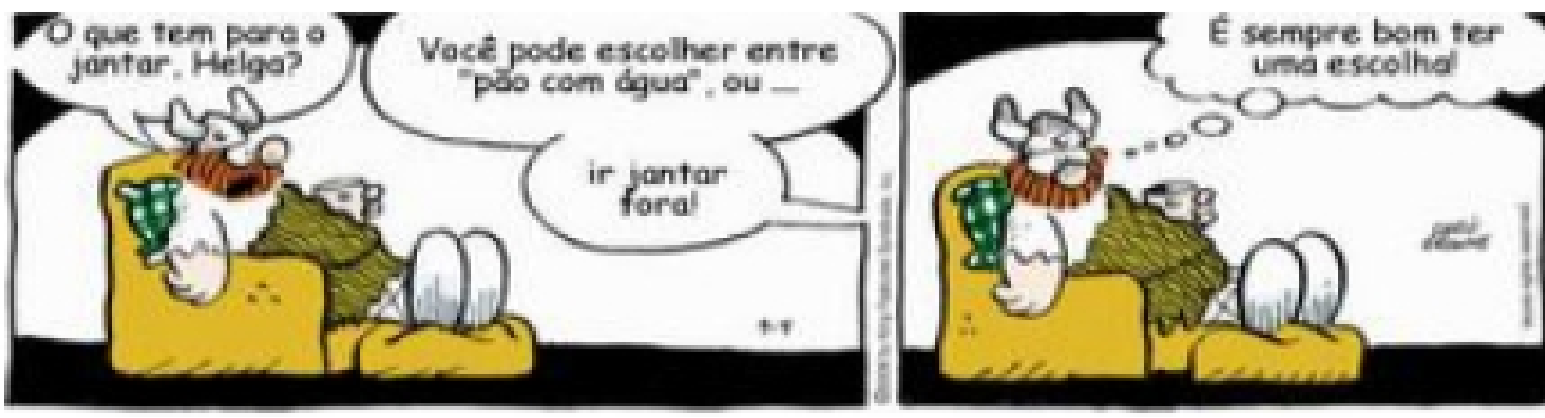

a) Observem o $2^{\circ}$ quadrinho da tira. Nele, existe um período composto por duas orações: "É sempre bom ter uma escolha". Dividam essas orações.

b) Podemos observar que, na 1a oração, há a presença do verbo de ligação "é" e do predicativo do sujeito "sempre bom". Qual termo está ausente dessa oração?

c) $\mathrm{O}$ termo que não está presente na $1^{\underline{a}}$ oração existe nesse período analisado? Pode-se afirmar que esse termo é formado por uma oração? Expliquem como isso é possível.

d) Pode-se, portanto, concluir qual é a função da $2^{\underline{a}}$ oração em relação à $1^{a}$ ? Expliquem.

e) Observem a $2^{\underline{a}}$ oração e verifiquem: não há uma conjunção ligando-a à $1^{\text {a }}$ oração e seu verbo não está desenvolvido, mas sim no infinitivo. Essas são características das orações reduzidas, que podem ser de infinitivo, gerúndio ou particípio.

f) Considerando todas as questões respondidas acima, como as orações desse período serão classificadas?

(Disponível em: http://comicshagar.blogspot.com/2008 0601 archive.html)

Fonte: http://portaldoprofessor.mec.gov.br/fichaTecnicaAula.html?aula=37814. 
Ainda que se baseiem na tirinha, as questões desse exercício ignoram completamente a produção de sentidos e não exploram características essenciais para a construção da significação nesse gênero, como a relação entre texto verbal e não verbal. Dessa forma, o exercício desperdiça o vínculo entre os eixos dos CL e da leitura. Os textos são meros pretextos para a identificação e a classificação de estruturas linguísticas, o que impossibilita a reflexão sobre a língua.

A utilização da tirinha com o único propósito de extrair frases para "dissecar" sintaticamente denota, nessa proposta, uma limitação às atividades metalinguísticas. Essa limitação é um traço da abordagem morfossintática tradicional dos CL que pudemos observar em todas as aulas de nosso corpus nela categorizadas, uma vez que essas aulas se caracterizam por focalizarem somente a estrutura da língua e a prescrição gramatical.

Os exemplos da abordagem morfossintática tradicional que analisamos permitem-nos observar que esse tipo de abordagem dos CL deixa de possibilitar aos alunos o desenvolvimento de um olhar científico e crítico sobre a língua e os seus usos $^{10}$. Assim, a abordagem morfossintática tradicional é incompatível com a prática de AL. A visão acerca do que seja a prática da $\mathrm{AL}$, oriunda dos docentes que elaboraram as aulas tipificadas nessa abordagem, encontra-se, portanto, bastante distorcida.

\subsection{Abordagem sintático-semântica em consonância com nomenclaturas e conceitos da GT}

Como pontuamos em nossa metodologia, a análise dos dados mostrou-nos que existem, entre as aulas analisadas, diferentes nuances em relação à abordagem adotada no tratamento dos CL. Há abordagens que mesclam características da abordagem tradicional a contribuições dos estudos do texto, com maior ou menor influência de

\footnotetext{
${ }^{10}$ Cf. Perini (2014).
} 
cada um desses paradigmas. É o caso da abordagem sintático-semântica em consonância com nomenclaturas e conceitos da GT, que se caracteriza por essa "mescla".

Nessa abordagem, a exploração dos sentidos é realizada de maneira superficial e a sua relação com os CL limita-se às possibilidades da GT, isto é, aos seus conceitos e às suas nomenclaturas. Entre as aulas nela categorizadas está a aula 8, que se intitula "As orações subordinadas adjetivas na construção do texto". Essa aula dá indícios de sua filiação à abordagem sintático-semântica em consonância com nomenclaturas e conceitos da GT desde o título, que utiliza da metalinguagem gramatical para tratar das orações adjetivas e, ao mesmo tempo, aponta para o papel dessas orações na construção do texto.

Ao lado de questões que exploram os sentidos do texto de modo superficial, há nessa aula questões que se limitam à classificação e à identificação, contraste que constitui um traço típico das aulas que categorizamos nesta abordagem. No que diz respeito à aula em análise, a tentativa de aproximação ao trabalho com a reflexão e os sentidos, aliada à manutenção do foco na metalinguagem, é demonstrada na primeira atividade, apresentada no Exemplo 3: 
Exemplo $3-1^{\mathrm{a}}$ atividade da aula 8.

Aula 1 (50 minutos)

Professor, o tema a ser abordado nessa aula trata-se das orações subordinadas adjetivas. Essas orações servem para caracterizar, especificar os seres e objetos que nos cercam, generalizando ou particularizando um determinado nome. As adjetivas restritivas possibilitam ao produtor conceituar com precisão, eliminar ambiguidades e indeterminações de nomes e pronomes, enquanto as explicativas funcionam especificamente para se dar ênfase a determinados dados ou conceitos. $\mathrm{O}$ emprego das orações subordinadas adjetivas é bastante produtivo, principalmente, em anúncios publicitários. Quando o anunciante opta pelo emprego de uma oração subordinada adjetiva, ele pode excluir outros produtos, evidenciando apenas um entre muitos.

Atividade

O professor deverá levar os alunos ao laboratório de informática para, em dupla, pesquisarem sobre pronome relativo e orações subordinadas adjetivas. Durante a pesquisa, os alunos deverão fazer anotações relativas ao assunto pesquisado, atendendo ao seguinte roteiro:

1. Pronome relativo: conceito e emprego e função.

2. Quadro dos pronomes relativos: variáveis e invariáveis.

3. Orações subordinadas adjetivas: conceito e classificação.

Disponíveis nos sites:

http://pt.wikipedia.org/wiki/Pronome_relativo

http://www.brasilescola.com/gramatica/pronomerelativo.htm

Observação: professor, esta atividade de pesquisa poderá também ser realizada em gramáticas dentro da sala de aula, ou na biblioteca da escola.

Fonte: http://portaldoprofessor.mec.gov.br/fichaTecnicaAula.html?aula=19803.

Na introdução dessa atividade, ao dirigir-se aos professores, o professor-autor conceitua as orações subordinadas adjetivas com base na gramática tradicional e, dentro dos limites do que possibilita esse conceito, indica o papel dessas estruturas linguísticas na produção de sentidos. Ainda que ocorra de forma limitada à definição tradicional, essa menção à importância das orações para que os textos alcancem seus propósitos comunicativos mostra certa influência dos estudos linguísticos do texto nessa aula. Todavia tal influência fica restrita às orientações introdutórias ao professor, não alcançando a proposta de atividade em si. Por sugerir que os estudantes pesquisem conceitos e classificações do conteúdo gramatical a ser estudado, em vez de induzi-los à construção desses conceitos por meio da reflexão linguística baseada em textos, a atividade deixa clara a priorização da metalinguagem e do reconhecimento 
de estruturas. Diferentemente do que é apontado nos objetivos da aula, nessa atividade de pesquisa os CL não são mobilizados a favor dos sentidos.

A relação entre CL e produção de sentidos surge na segunda atividade da aula. No entanto, a metalinguagem permanece em destaque por meio de questões de identificação e classificação que, apesar de não corresponderem à totalidade das propostas (como ocorre nas aulas da abordagem que analisamos anteriormente), são predominantes. No Exemplo 4, observaremos trechos dessa segunda atividade, que consiste na análise de orações subordinadas adjetivas em anúncios publicitários:

Exemplo 4 - Trechos da $2^{\mathrm{a}}$ atividade da aula 8.

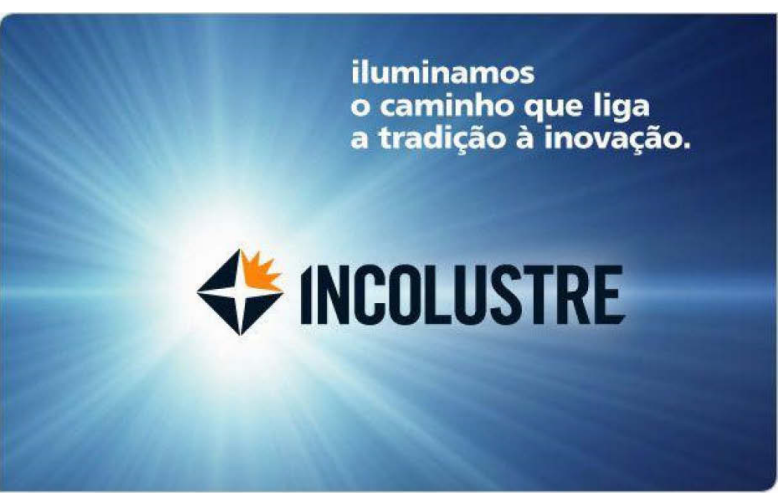

2. Observe o anúncio 2

Iluminamos o caminho que liga a tradição à inovação.

a. Identifique o pronome relativo e o substantivo que ele retoma no anúncio.

b. Como se classifica a oração subordinada? Por quê?

c. O sujeito da forma verbal 'iluminamos' - nós - está subentendido. Considerando o contexto, é possível identificar a quem esse pronome se refere?

Fonte: http://portaldoprofessor.mec.gov.br/fichaTecnicaAula.html?aula=19803

Ocorre nessa atividade uma tentativa de "contextualização" de noções da gramática tradicional. Como indicam Antunes (2014) e Mendonça (2007), essa "gramática contextualizada" por vezes camufla a supervalorização da metalinguagem através de um trabalho insuficiente com o texto. É o que ocorre nas perguntas sobre o anúncio apresentado no exemplo acima. Apesar de serem baseadas no texto (anúncio publicitário), essas perguntas não tratam de seus propósitos comunicativos, tampouco de suas possibilidades de compreensão. 
Na letra "a." dessa questão, solicita-se a identificação do pronome relativo presente no anúncio e do substantivo que ele retoma sem que seja explorado o papel dessa relação de "retomada" para a construção do texto. Dessa maneira, o objetivo desse item reduz-se a "checar" a apropriação da metalinguagem pelos estudantes. Na letra "b.", que trata especificamente da oração subordinada, pergunta-se apenas sua classificação, sem qualquer estímulo à reflexão sobre o seu papel na produção de sentidos.

Apenas na letra "c." dessa questão a produção de sentidos é, em certa medida, explorada, já que os estudantes são levados a inferir por meio do contexto que o sujeito implícito "nós" refere-se à empresa que promove o anúncio. No entanto esse trabalho com os sentidos é superficial. Não se explora, por exemplo, a relação entre a escolha desse sujeito e a intenção de atribuir "pessoalidade" à empresa anunciante, nem a relação entre o sentido da expressão "iluminamos o caminho" e a natureza da empresa que promove o anúncio (trata-se de uma empresa de iluminação); tampouco se observa como a composição imagética do anúncio corrobora o sentido do texto.

As características das aulas vinculadas à abordagem sintático-semântica em consonância com nomenclaturas e conceitos da GT, que pudemos discernir com base na análise dos exemplos, permitem-nos constatar que tais aulas não são compatíveis aos temas relacionados à AL em que foram classificadas no Portal pelos professoresautores. Nas aulas da abordagem sintático-semântica em consonância com nomenclaturas e conceitos da GT, a profundidade das reflexões linguísticas promovidas e da relação entre CL e produção de sentidos oscila de uma proposta para a outra, mas nunca chega a ultrapassar os limites da GT. Isso significa a não exploração do contexto, sendo o texto sempre tomado como pretexto e a significação abordada apenas no nível da estrutura ou do sistema. Ou seja, o texto é colocado, mas não explorado do ponto de vista da significação. 
Em nosso corpus existem, no entanto, aulas que, apesar de não alcançarem a abordagem textual-discursiva dos CL, desvinculam-se da primazia metalinguística e, assim, exploram os CL de maneira mais aprofundada do que as aulas das abordagens morfossintática tradicional e sintático-semântica em consonância com nomenclaturas e conceitos da GT. Tais aulas correspondem às da abordagem sintático-semântica a partir do texto.

\subsection{Abordagem sintático-semântica a partir do texto}

Diferentemente do que ocorre na abordagem sintático-semântica em consonância com nomenclaturas e conceitos da GT, na abordagem sintático-semântica a partir do texto, o tratamento dos CL realiza-se de maneira menos fixada à prescrição e aos conceitos da gramática tradicional. Essa característica é demonstrada por um uso atenuado da metalinguagem gramatical, que se circunscreve aos momentos de sistematização das reflexões ou, em alguns casos, nem mesmo é utilizada.

Uma das aulas tipificadas em tal abordagem é a aula 6, intitulada "As conjunções nos artigos de opinião". Como indica o título, nessa aula há o intento de versar sobre a classe de palavras em estudo fundamentado em seus usos. Assim, ela sinaliza desde o título um dos atributos da abordagem sintático-semântica a partir do texto: a exploração dos CL por meio de sua função no texto. A presença desse atributo pode ser constatada na primeira atividade dessa aula, como veremos no exemplo: 
Exemplo $5-1^{\text {a }}$ atividade da aula 6.

Atividade 1

As conjunções têm um papel importante na articulação entre as partes de um texto, contribuindo para a coesão textual, guiando o leitor, uma vez que indicam a relação existente entre as orações e as frases. Focaremos nessa aula mais especificamente a utilização das conjunções em artigos de opinião. Para que os alunos percebam a importância dos elementos coesivos na construção dos artigos de opinião, o professor entregará o artigo de opinião a seguir, que foi adaptado retirando-se dele as conjunções, que foram substituídas símbolo $\varnothing$.

Nessa atividade, sugerimos a seguinte sequência:

1. Os alunos deverão fazer uma primeira leitura, individualmente, tentando identificar o que poderia ser colocado no lugar dos espaços onde aparece o símbolo " $\varnothing$ ".

2. Em seguida, os alunos, alternadamente, lerão o texto em voz alta, sendo que a cada vez que aparecer o símbolo $\varnothing$ um aluno deverá dizer o que poderia ser colocado naquela posição do texto.

3. Tendo feito a segunda leitura, discutir qual o tema está sendo discutido no texto e qual a tese defendida pelo autor do mesmo, bem como qual a relação entre o título do texto e seu conteúdo.

4. Por fim, o professor discutirá com os alunos o papel das palavras que foram suprimidas, ressaltando que, embora seja possível interpretar o texto sem as palavras que foram suprimidas do original, elas têm um papel importante que é o de estabelecer uma articulação entre as diversas partes do texto.

5. Em seguida, o professor entregará a versão original do artigo, com as conjunções presentes e destacadas, para que os alunos percebam como elas auxiliam na ligação entre as partes do texto, tanto no interior das frases, quanto na relação entre uma frase e outra, um parágrafo e outro.

\section{A lei do silêncio dos advogados}

Rogério Gentile

20/11/2014 02h00

SÃO PAULO

As revelações sobre o Petrolão têm preocupado $\varnothing$ políticos e executivos de empreiteiras $\varnothing$ advogados importantes que, normalmente, ganham muito dinheiro quando surgem escândalos de corrupção. O motivo é a tal "delação premiada", mecanismo pelo qual vários acusados, entre os quais o ex-diretor da Petrobras Paulo Roberto Costa, estão entregando colegas, corruptos e corruptores, em troca da redução de suas penas. Basicamente, reclamam que as acusações feitas mediante recompensa não merecem crédito $\varnothing$ o delator não tem compromisso com a verdade, $\varnothing$ com a sua sobrevivência falaria qualquer coisa para melhorar a própria situação. $\varnothing$ dizem que não é ético o Estado barganhar com um criminoso. [...]

Fonte: http://portaldoprofessor.mec.gov.br/fichaTecnicaAula.html?aula=58736.

Nessa atividade, realiza-se a introdução do conteúdo da aula de maneira indutiva. Os alunos são apresentados a um texto do qual foram retiradas as conjunções e, com base em sua leitura, são levados a raciocinar a respeito da finalidade das palavras suprimidas e a construir, através de seus próprios repertórios vocabulares, "soluções" para a falta de articulação que certamente será detectada. Com isso, os CL em estudo são trabalhados através de seu papel para a estruturação do texto. Também 
é interessante notar que, mesmo tendo foco na função das conjunções, a atividade não exclui o trabalho com os sentidos do texto, como mostra a questão 3, em que se propõe a discussão sobre a tese defendida pelo autor (cuja presença é uma característica do gênero textual estudado) e a relação entre o conteúdo do artigo de opinião e o seu título.

Dessa forma, a primeira atividade da aula 6 promove a articulação entre os eixos da leitura e os dos CL. Essa articulação proporciona reflexões linguísticas mais significativas e promove o trabalho com os CL a favor do desenvolvimento das habilidades de uso da língua - o que aproxima a atividade do que propõe Geraldi (1997, 2006) para a prática de AL. A compreensão do valor das conjunções para a composição textual é um passo importante para que os estudantes sejam capazes de discernir o que a escolha de um articulador em lugar de outro indica sobre as intenções e os posicionamentos de um autor, o que é fundamental para formação de leitores e de cidadãos que não são facilmente manipuláveis. Como defende Antunes (2014), o desenvolvimento desse tipo de perspicácia linguística consiste em uma das responsabilidades sociais do ensino de língua portuguesa.

No entanto, ao lado de atividades como essa, há nas aulas da abordagem sintático-semântica a partir do texto propostas em que falta a exploração plena da produção de sentidos, ainda que o papel dos CL na significação seja trabalhado. Essa característica da abordagem em análise pode ser observada na continuidade da aula 6, como mostra o exemplo seguinte: 
Exemplo $6-2^{\mathrm{a}}$ atividade da aula 6.

O professor dividirá a turma em duplas para que eles façam a próxima atividade:

Os alunos receberão os artigos de opinião a seguir e deverão:

1. Marcar no texto (circular ou sublinhar) os elementos articuladores.

2. Identificar qual o valor semântico de cada um dos elementos articuladores encontrados.

3. Indicar (com um asterisco) as passagens em que poderiam ser utilizados outros conectivos (escrevendo sobre o elemento utilizado um outro com mesmo sentido).

4. Marcar no texto (com um triângulo) eventuais locais onde o autor não utilizou conectivos, mas que poderia ser acrescentado (indicando qual tipo de conectivo seria possível).

1

$\underline{\text { Temas ausentes }}$

Mario Cesar Flores O.

Estado de S. Paulo

19 Novembro 2014 | 02h

Disponível em: http:/opiniao.estadao.com.br/noticias/geral,temasausentesimp,1594878. Acesso em: 20 nov. 2014.

Texto 2

Arbitrariedades e aparelhamento político nas escolas públicas

Publicado em 20/11/2014 I Thiago Melo

Disponível em:

http://www.gazetadopovo.com.br/opiniao/conteudo.phtml?tl=1\&id=1514864\&tit=Arbitrariedadeseaparelhame ntopoliticonasescolaspublicas. Acesso em: 20 nov. 2014

Fonte: http://portaldoprofessor.mec.gov.br/fichaTecnicaAula.html?aula=58736.

Assim como a primeira atividade dessa aula, a atividade acima trata das conjunções alicerçada no papel por elas desempenhado no texto. O exercício proposto estimula o estudante a comparar e a estabelecer relações de equivalência entre os articuladores em estudo, além de aproximar-se da já mencionada proposta de Franchi (2006) de reelaborar estruturas linguísticas ao propor que os alunos modifiquem trechos em que não há uso de conjunções empregando esses articuladores de acordo com o sentido adequado. Há, todavia, algumas limitações quanto ao trabalho com a produção de sentidos e a reflexão linguística nessa proposta.

Em relação à exploração da produção de sentidos, podemos constatar que o aprofundamento necessário não ocorre na atividade acima porque os dois artigos de opinião sugeridos são tomados apenas como repositórios de exemplos. Não se considera, por exemplo, como o uso das conjunções repercute para a articulação dos parágrafos ou para a significação global dos artigos. Os sentidos produzidos por cada 
texto - que se relacionam ao seu público-alvo, ao contexto de publicação, às particularidades do gênero, ao lugar de fala dos autores (já que se trata de artigos de opinião) - também não são levados em consideração. Apesar de ser intitulada "As conjunções nos artigos de opinião" e apresentar como um de seus objetivos o trabalho específico com os articuladores no gênero indicado, a aula não promove a apreensão das especificidades desse gênero (nem as que se referem às características gerais dos artigos de opinião nem àquelas que dizem respeito ao uso das conjunções nesses artigos).

Já em relação à reflexão linguística, afora as já mencionadas restrições que se apresentam como consequência do trabalho limitado com a significação, a apresentação de um quadro que lista os articuladores de acordo com as circunstâncias por eles expressas - o qual, de acordo com o que propõe o professor-autor, antecede a atividade do exemplo 6 - pode levar os estudantes a apenas identificar e "copiar" as conjunções que indicam a mesma circunstância ao responderem às perguntas do exercício, o que torna superficiais as reflexões promovidas na atividade.

Nessa aula, é interessante atentarmos ainda para a presença de outra característica da abordagem sintático-semântica a partir do texto: o uso atenuado da metalinguagem gramatical. Ao observarmos os exemplos, é possível notar que a metalinguagem é utilizada apenas nas orientações direcionadas aos professores. Enquanto os enunciados dirigem-se aos alunos, por exemplo, o termo "conjunções" não é utilizado; utilizando-se a denominação "articuladores". Da mesma maneira, ao serem apresentados os valores semânticos de cada grupo de conjunções, estes não são postos como uma "classificação" predefinida por meio da subordinação e da coordenação, como o faz a GT, mas apresentados como uma consequência dos usos (embora sem contexto específico) que determinam os valores semânticos aí identificados. 
O uso moderado da metalinguagem nas aulas da abordagem sintáticosemântica a partir do texto está atrelado a uma menor presença de atividades metalinguísticas nessas aulas (quando comparadas àquelas das abordagens morfossintática tradicional e sintático-semântica em consonância com nomenclaturas e conceitos da GT).

As aulas da abordagem sintático-semântica a partir do texto mostram que a visão de seus professores-autores acerca do conceito de $A L$, se comparada àquelas vinculadas às abordagens anteriormente analisadas, tem maior proximidade ao que propõe Geraldi (2006, 1997) e ratificam Franchi (2006), Antunes (2014) e Mendonça (2007). As aulas revelam que esses professores-autores têm, provavelmente, conhecimento das contribuições para o ensino de língua portuguesa provenientes dos estudos da linguística voltados para o texto e para o discurso, e que se empenham em colocá-las em prática. Entretanto ainda há em suas propostas indícios do apego ao ensino tradicional de gramática. Como vimos em nossa análise, esses indícios manifestam-se nas propostas da abordagem sintático-semântica com base no texto, porém sempre em menor grau do que aqueles presentes nas abordagens anteriores.

\subsection{Abordagem teórica de conceitos da linguística}

A quarta abordagem dos CL identificada em nossa análise, a abordagem teórica de conceitos da linguística, também reflete certo domínio dos professores-autores em relação às contribuições da linguística para o ensino de português. Porém, como veremos a seguir, esse domínio manifesta-se nas aulas de maneira distinta do que observamos nas abordagens até agora analisadas.

São aulas da abordagem teórica de conceitos da linguística aquelas que abordam de maneira predominantemente teórica - ou seja, priorizando a elucidação de noções e de concepções em detrimento do estímulo à reflexão e às habilidades de uso da língua - teorias ou conceitos relacionados aos CL provenientes de estudos da 
linguística. Uma das aulas de nosso corpus tipificadas nessa abordagem dos CL é a intitulada "Variação linguística na sala de aula". Essa aula tem como foco a explanação do conceito de variação linguística e seus tipos, com maior destaque para a variação diatópica. Vejamos a primeira parte de suas atividades:

Exemplo $7-1^{\mathrm{a}}$ atividade da aula 4.

\section{Estratégias e recursos da aula}

O trabalho com a variação linguística nos textos literários tem se expandido em meio as práticas pedagógicas porque a língua portuguesa é muito rica no que tange a variedade linguística devido à dimensão continental do país, a diversidade de nossa literatura e a migração de pessoas principalmente da Região Sul para a Região Centro-Oeste que contribui para a variação linguística ser mais acentuada em nossa região.

\section{Sequência Didática}

O professor deve ter bem definido quais as variações linguísticas que pretende trabalhar com sua turma antes de dar início a esta sequência. Assim poderá explorar as variações existentes na sala de aula prevista para esse trabalho: Variedade Geográfica, Variedade Diacrônica, Variedades Sociais e Variedades Situacionais, bem como trabalhar a leitura, a interpretação e a produção de textos, utilizando as variações linguísticas com o objetivo de conhecer e identificar as mesmas nas diferentes regiões do país.

1aㅗ Atividade

Esta aula inicial tem o objetivo específico de ampliar o vocabulário da turma em relação à variação linguística. Antes de iniciar a leitura o professor deve sondar os conhecimentos que os alunos já têm em relação às variações geográficas. Perguntar oralmente aos alunos onde nasceram? De qual região pertencem? Se eles conhecem as marcas da linguagem de sua região? Percebem as diferenças entre o vocabulário da região de origem e aquela falada onde eles vivem ou residem? Agora o professor pode projetar no Data Show um trecho do poema de Oswald de Andrade, que está abaixo:

\section{Vício na fala}

Para dizerem milho dizem mio

Para melhor dizem mió

Para pior pió

Para telha dizem teia

Para telhado dizem teiado

E vão fazendo telhados.

(Oswald de Andrade)

Fonte: http://www.brasilescola.com/gramatica/variacoes-linguisticas.htm

- Perguntar aos alunos se eles percebem a variação linguística dentro do texto? ${ }^{11}$

- Pedir para que os alunos digam as variações encontradas.

- Pedir aos alunos se é comum encontrar esse tipo de variação no local onde ele mora?

Fonte: http://portaldoprofessor.mec.gov.br/fichaTecnicaAula.html?aula=42619.

\footnotetext{
${ }^{11}$ Assim como todos os exemplos apresentados neste trabalho, essa proposta foi transcrita da mesma maneira que está publicada no Portal do Professor.
} 
Analisando a própria escolha do conteúdo abordado e as orientações iniciais direcionadas aos professores, nota-se nessa aula que o professor-autor busca aliar os estudos da linguística sobre a variação ao ensino-aprendizagem de português. Essa busca constitui um passo relevante para o tratamento dos CL a favor do texto, uma vez que é na perspectiva da variação que ocorrem as reflexões significativas sobre os usos reais da língua ${ }^{12}$. No entanto, de maneira condizente à abordagem em que a aula foi classificada, o trabalho com a variação linguística nessa atividade é realizado de forma pouco propícia à reflexão, priorizando a simples identificação de variantes no texto.

Nas orientações direcionadas ao professor que dão início à proposta (primeiro parágrafo do Exemplo 7), é possível notar o enfoque direcionado à variação diatópica quando é mencionada a relação entre a importância que adquiriu o estudo da variação linguística e a dimensão continental do Brasil. Há, nesse trecho, alguns indícios de equívocos conceituais; o professor-autor parece atribuir o fenômeno da variação linguística de forma geral a fatores geográficos, como a amplitude do país e os fluxos migratórios. Isso fica evidente na afirmação de que a variação seria mais "acentuada" na região centro-oeste graças às migrações provenientes do sul.

No prosseguimento das orientações ao professor (terceiro parágrafo do Exemplo 7), propõe-se que a atividade tenha início com uma sondagem do que os alunos já sabem em relação à variação linguística. Além de considerar o conhecimento prévio dos estudantes, essa conversa inicial é pautada por perguntas que conduzem à apresentação do conceito de variação linguística como um fenômeno natural da língua, que está no cotidiano de todos os falantes. Contudo, nessas perguntas, é possível observar mais uma vez que são considerados exclusivamente fatores relacionados à variação diatópica, o que contribui para uma espécie de estereotipação do conteúdo variação linguística.

\footnotetext{
${ }^{12}$ Cf. Ilari e Basso (2011).
} 
A primeira parte da aula é concluída com a sugestão de leitura do poema “Vício na fala", seguida de algumas perguntas que relacionam o texto ao conteúdo trabalhado. Esse é o trecho da primeira parte da aula em que ficam mais evidentes as características da abordagem teórica de conceitos da linguística, pois as perguntas sugeridas requerem apenas a identificação de "variações" (não fica claro se o que se pede é a identificação das variantes utilizadas ou de palavras/expressões que se apresentam de forma diversa da norma culta).

Assim, o exercício não propicia reflexões que poderiam levar os alunos, através da observação e da análise da língua em uso, a compreender a maleabilidade e a mutabilidade que fazem parte da natureza da língua. Ademais, a crítica presente no poema, que envolve o entrelace entre preconceito social e preconceito linguístico, não é discutida. A ausência dessa discussão aumenta a lacuna deixada pela atividade, já que seu desenvolvimento possibilitaria a exploração dos sentidos do texto de forma atrelada aos CL em foco.

A análise das características da abordagem teórica de conceitos da linguística nos leva a constatar que os professores-autores que elaboraram as aulas que tipificamos em tal abordagem, mesmo tendo certo conhecimento das contribuições da linguística para o ensino de português e esforçando-se por aplicá-las, confundem a prática de AL com o ensino "puro" de conceitos da linguística.

\subsection{Abordagem textual-discursiva}

Trataremos agora de propostas nas quais a abordagem dos CL é realizada de modo que é possível identificar uma metodologia de AL: as propostas tipificadas na abordagem textual-discursiva. Nas aulas que classificamos nessa abordagem, o estudo dos CL é realizado, majoritariamente, com vistas à compreensão do funcionamento e da natureza da língua. Para tanto, ela é analisada com base em seus usos reais, quer dizer, efetivamente alicerçada em textos. Visto que todo uso real da língua promove 
sentido, nessa abordagem o estudo dos CL é sempre vinculado ao trabalho com a significação. São privilegiadas, então, as atividades epilinguísticas, reservando-se as metalinguísticas para os momentos em que é preciso fazer referência a estruturas linguísticas já conhecidas dos estudantes ou sistematizar ideias provenientes de atividades epilinguísticas previamente desenvolvidas.

Uma das aulas tipificadas nessa abordagem é a aula 29, intitulada "Variação linguística, que preconceito é esse?". Em virtude de sua construção sintática, o título da aula dá margem para a interpretação do que seria um equívoco conceitual, pois com base nele é possível interpretar que o próprio fenômeno da variação linguística é um preconceito. No entanto tal equívoco circunscreve-se ao título. Diferentemente do que vimos na aula 4 (pertencente à abordagem teórica dos conceitos da linguística), em que o mesmo conteúdo é abordado de maneira predominantemente teórica, nessa aula o fenômeno da variação é estudado em prol do desenvolvimento da reflexão e da análise linguísticas. Tais características podem ser observadas no exemplo a seguir, em que se propõe uma atividade acerca da variação diatópica:

Exemplo $8-2^{\mathrm{a}}$ atividade da aula 29

Mostre uma notícia sobre a atriz Grazielli Massafera.

Acesse o link: http://sitedaescola.com/aulas inovadoras/keila/noticia grazi.pdf

O sotaque da paranaense Grazielli Massafera, 22 anos, provocou polêmica nesta semana. Uma revista e um jornal de São Paulo noticiaram que a ex-Big Brother Brasil fará sessões de fonoaudiologia para corrigir a maneira de falar considerada "caipira". Grazi, por meio de sua assessoria de imprensa, confirmou a notícia, justificando que pretende amenizar o som do " $\mathrm{r}$ " retroflexo (o " $\mathrm{r}$ " caipira") para ampliar as suas possibilidades profissionais e não ficar restrita a personagens como a Thelminha, da novela Páginas da Vida, e Florinda, de Desejo Proibido.

Mas, afinal, existe uma maneira certa de falar? Isso seria um problema do sotaque paranaense? A professora da Universidade Estadual de Londrina (UEL) Vanderci de Andrade Aguilera, doutora em Lingüística, garante que ninguém fala errado. "Todo mundo fala certo de acordo com a comunidade em que está inserido", afirma. Ela explica que o sotaque de Grazi, comum em Jacarezinho, cidade natal da atriz, é resultado do contato dos indígenas com os portugueses. “Os bandeirantes absorveram essa maneira de falar e levaram essa fala para o Sul de Minas Gerais e Norte de São Paulo", esclarece. Posteriormente, mineiros e paulistas "A fala de quem tem prestígio tende a ser imitada", observa Vanderci Aguilera, autora do Atlas Lingüístico do Paraná. Ela recorda que, em 1808, quando D. João VI chegou ao Rio de Janeiro, a fala do interior paulista - o " $\mathrm{r}$ " retroflexo - perdeu prestígio para o sotaque da "corte", o mesmo que hoje é falado pelos cariocas. 
Peça que os grupos respondam as questões abaixo, registrando no caderno para, em seguida, apresentarem ao restante da turma:

- Com base na reportagem acima, vocês concordam com a opinião da professora Vanderci Aguilera? Por quê?

- Qual sua opinião sobre Graziela ser obrigada a estudar para aprender o sotaque "global" para não ficar "restrita a papeis como o de Telminha"? Conhecem alguém que passou pela mesma situação?

- Você considera tal atitude preconceituosa? Por quê? Caso considere, responda: que tipo de preconceito é esse?

- Já percebeu que na maior rede de televisão brasileira existe um padrão de fala? Qual é esse padrão?

Reforce com os alunos que hoje em dia ainda há um grande equívoco que já se transformou preconceito por parte de algumas pessoas que entendem que uma variante é melhor que as outras, desprestigiando pessoas com o sotaque ou variante diferente do seu, a presença do preconceito é muito comum na fala chamada caipira, ou de grupos nordestinos, isto são os chamados preconceitos linguísticos, nesse sentido, e ele deve ser combatido. As diferentes variantes de uma língua devem ser vista como algo rico culturalmente, e que faz parte da identidade de cada um. Seria muito interessante se existisse em sua sala de aula uma pessoa de outra etnia, ou de origem diferente da sua, seria uma excelente oportunidade para conhecer uma cultura diferente.

Fonte: http://portaldoprofessor.mec.gov.br/fichaTecnicaAula.html?aula=44004.

Para responder à primeira pergunta após a leitura da reportagem, que questiona o posicionamento dos alunos acerca do que defende a linguista Vanderci Aguilera, os estudantes poderão recorrer à reflexão à qual foram estimulados no que se refere ao funcionamento da variação nos diferentes níveis de análise da língua (fonológico, morfossintático e semântico-lexical). Essa reflexão também pode ser retomada na elaboração das respostas para as demais perguntas da atividade, que fomentam o debate sobre o prestígio atribuído às variantes de determinadas regiões do país e sobre o preconceito sofrido por outras.

A reflexão sobre o preconceito linguístico é promovida nessa atividade a partir de um exemplo que faz parte do cotidiano de uma parcela significativa da população - o sotaque "padronizado" das redes televisivas. Isso instiga os alunos a observarem com maior criticidade eventos do dia a dia que envolvem a linguagem e a notarem como o caráter social da língua faz com que se reflitam em seus usos as relações de poder que permeiam a vida em sociedade. A atividade provoca, portanto, a 
conscientização dos alunos sobre a existência do preconceito linguístico e a ausência de fundamentos para a sua existência. A abordagem desse conteúdo de forma reflexiva consiste em uma contribuição importante da linguística para o ensino de língua portuguesa, capaz de modificar uma problemática que há muito se perpetua na escola: a fomentação de preconceitos linguísticos e sociais decorrente de práticas que priorizam a normatividade gramatical ${ }^{13}$.

As características observadas na proposta da abordagem textual-discursiva mostram-nos que existe, da parte de seus professores-autores, a compreensão do que se propõe para a prática de AL. Assim, diferentemente do que observamos nas demais abordagens, as aulas dessa abordagem são compatíveis aos temas relacionados à $\mathrm{AL}$ em que foram classificadas no Portal. Isso pode ser afirmado graças ao fato de que elas tratam dos CL de maneira articulada aos demais eixos de ensino da língua portuguesa, promovendo a reflexão sobre a língua fundamentada em seus usos (que se materializam em textos).

Nas análises das aulas de diferentes abordagens dos CL que realizamos até aqui, pudemos observar os diferentes níveis de alcance das propostas de prática de AL no que é projetado para as aulas de português e, por conseguinte, como os professoresautores compreendem essa prática. Dessas constatações, trataremos na seção a seguir.

\section{Considerações finais}

Qual o alcance das contribuições dos estudos linguísticos sobre o texto e sobre o discurso que projetam os professores-autores do Portal para a abordagem dos CL? O que os professores participantes do Portal (autores e usuários) entendem por AL? Essas perguntas, que suscitaram os objetivos traçados para a nossa pesquisa, foram respondidas ao longo do desenvolvimento deste trabalho de maneira distinta de nossa

\footnotetext{
${ }^{13}$ Cf. Possenti (1996).
} 
expectativa inicial. Isso porque não há resposta única para cada uma delas. Tais perguntas são respondidas de maneira diferente para cada abordagem dos CL que tipificamos.

Acerca do alcance das contribuições dos estudos linguísticos que relacionam os CL ao texto e ao discurso, identificamos níveis diferentes de influência em cada uma das cinco abordagens. Deparamo-nos, então, com um espectro que vai da influência quase nula - nas aulas da abordagem morfossintática tradicional - a casos em que as contribuições desses estudos aparecem de maneira coerente e bem consolidada - na aula da abordagem textual-discursiva. A maior parte das aulas analisadas, no entanto, concentra-se em abordagens intermediárias, isto é, que mantêm alguns traços do ensino tradicional de gramática ao mesmo tempo em que revelam, em maior ou menor grau, a influência dos estudos linguísticos que fundamentam a abordagem textualdiscursiva - são elas as abordagens "sintático-semântica em consonância com nomenclaturas e conceitos da GT" e "sintático-semântica a partir do texto".

Nossa análise permitiu-nos observar, ainda, que, nas propostas publicadas no Portal do Professor, a persistência das características da abordagem tradicional não se deve a um completo desconhecimento, por parte dos docentes, das contribuições da linguística para o trabalho com os CL. Mesmo em aulas tipificadas na abordagem morfossintática tradicional, pudemos observar indícios de certa "familiaridade" dos professores-autores com conceitos e propostas dos estudos linguísticos: menções à existência de variantes linguísticas, aos gêneros textuais, aos processos de coesão e coerência etc.

Por isso, corroboramos o que argumentam Kleiman e Sepulveda (2012) quanto ao fato de que é na transposição didática que se encontra o principal impasse para a adoção de uma abordagem dos CL a favor da reflexão linguística. Consequen-temente, a universidade - na sua condição de esfera de formação docente inicial e continuada tem no trabalho com a transposição didática seu maior desafio em relação à formação 
de professores de língua portuguesa, sobretudo no que diz respeito ao eixo dos CL. Isso porque o desafio inicial de tornar as contribuições da linguística para o ensino conhecidas pelos professores tem sido superado, mas tal fato não garante que os docentes tenham segurança para se apropriar dessas teorias em suas práticas.

As atividades desenvolvidas pelos próprios professores para as suas práticas, proporcionadas pelas publicações do Portal do Professor, possibilitaram a constatação de que os fundamentos teórico-metodológicos da abordagem textual discursiva têm reverberado, ainda que de forma esparsa, no que almejam os professores para suas aulas. No entanto esse processo não ocorre linearmente e, dado o histórico de entrelace entre ensino de língua materna e gramática normativa, traz consigo desafios cuja superação exige a continuidade dos debates, das pesquisas e de proposições metodológicas que envolvam a abordagem dos CL.

\section{Referências}

ANTUNES, I. Aula de Português: encontro e interação. São Paulo: Parábola, 2003.

ANTUNES, I. Gramática Contextualizada: limpando o "pó das ideias simples". São Paulo: Parábola, 2014.

BEZERRA, B. G. Gêneros no contexto brasileiro: questões [meta] teóricas e conceituais. São Paulo: Parábola, 2017.

BEZERRA, M. A.; REINALDO, M. A. Análise Linguística: afinal, a que se refere?. São Paulo: Cortez, 2013.

BUNZEN, C. Ensino de Língua Portuguesa. In: FRADE, I. C. A. da S.; VAL, M. da G. C.; BREGUNCI, M. das G. de C. (orgs). Glossário Ceale: termos de alfabetização, leitura e escrita para educadores. Belo Horizonte: UFMG/Faculdade de Educação, 2014. DOI https://doi.org/10.31692/2526-7701.iicointerpdvagro.2017.00140

FRANCHI, C. Linguagem - Atividade Constitutiva. Cadernos de Estudos Linguísticos, n. 22, p. 9-39, 1977.

FRANCHI, C. Mas o que é mesmo “gramática”? São Paulo: Parábola, [1987] 2006. 
GERALDI, J. W. O texto na sala de aula. São Paulo: Ática, [1984] 2006.

GERALDI, J. W. Portos de passagem. 4. ed. São Paulo: Martins Fontes, 1997.

ILARI, R.; BASSO, R. O português da gente, a língua que estudamos, a língua que falamos. 2 ed. São Paulo: Contexto, 2011.

KLEIMAN, A. B ; SEPULVEDA, C. Oficina de gramática: metalinguagem para principiantes. Campinas: Pontes Editores, 2012.

MARCUSCHI, L. A. Produção textual, análise de gêneros e compreensão. São Paulo: Parábola, 2008.

MENDONÇA, M. Análise linguística no ensino médio: um novo olhar, um outro objeto. In: BUNZEN, C. ; MENDONÇA, M. (org.). Português no ensino médio e formação do professor. São Paulo: Parábola, 2006, p. 199-226. DOI https://doi.org/10.11606/t.48.2013.tde-27062013-153602

MENDONÇA, M. Análise linguística: refletindo sobre o que há de especial nos gêneros. In: SANTOS; C. F. ; CAVALCANTE, M. ; MENDONÇA, M. (org.). Diversidade textual: os gêneros na sala de aula. Recife/Belo Horizonte: MECCEEL/Autêntica, 2007.

NEVES, M. H. M. Que gramática estudar na escola? São Paulo: Contexto, 2015.

PERINI, M. Defino minha obra gramatical como a tentativa de encontrar respostas às perguntas: por que ensinar gramática? Que gramática ensinar? In: MOURA NEVES, H.; CASSEB-GALVÃO, V. (org). Gramáticas contemporâneas do Português: com a palavra, os autores. São Paulo: Parábola, 2014.

POSSENTI, S. Por que (não) ensinar gramática na escola. Campinas: Mercado das Letras, 1996. DOI https://doi.org/10.11606/issn.2176-9419.v0i2p265-271

POSSENTI, S. Gramática e política. In: GERALDI, J. W. (org). O texto na sala de aula. 5 ed. São Paulo: Ática, 1984, p. 47-56.

RANGEL, E. O. Livro didático de Língua Portuguesa: o retorno do recalcado. In: DIONISIO, A.; BEZERRA, M. A. (orgs). O livro didático de português: múltiplos olhares. 2. ed., Rio de Janeiro: Lucerna, 2001, p. 7-14. DOI https://doi.org/10.17771/pucrio.acad.16124 
SANTOS, H. Representações sociais dos professores de língua portuguesa sobre o ensino gramatical. Tese (Doutorado em Linguística). Programa de Pós-Graduação em Linguística, Universidade Federal de São Carlos, São Carlos, 2017. DOI https://doi.org/10.18605/2175-7275/cereus.v9n3p66-80

SOARES, M. Concepções de linguagem e o ensino de língua portuguesa. In: BASTOS, N. B. (org.). Língua portuguesa - história, perspectiva, ensino. São Paulo: Educ, 1998. DOI https://doi.org/10.11606/d.48.2014.tde-05022015-142241

SOARES, M. Que professores de português queremos formar? Movimento, n. 3, p. 149-155, maio 2001. 